\title{
VIABILITAS BENIH TERONG (SOLANUM MELONGENA L.) DENGAN PEMBERIAN POC BEKICOT

\author{
Intan Sari ${ }^{1}$, \\ ${ }^{1}$ Jurusan Agroteknologi, Fakultas Pertanian, Universitas Islam Indragiri, Tembilahan
} \\ Email: intansariunisi@gmail.com
}

\begin{abstract}
Research on the effect of liquid organic fertilizer (POC) of snails on eggplant (Solanum melongena L.) seed viability, was carried out from September to October 2018 at the Agrotechnology Laboratory of the Faculty of Agriculture, Jalan Parit Province. 1 Upstream. Research aims to determine the effect of giving Snail POC on eggplant seed viability (Solanum melongena L.) and gain concentration Snail POC optimal. The research design used was a non-factorial completely randomized design (CRD), consisting of 6 treatments, consisting of (without treatment, $20 \mathrm{ml}$ of Snail POC/liter of water, $30 \mathrm{ml}$ of Snail POC/liter of water, $40 \mathrm{ml}$ of Snail POC/liter of water, $50 \mathrm{ml}$ of snail POC). ml Snail POC/liter of water, 60 $\mathrm{ml}$ of Snail POC/liter of water and 3 replicates. statistically analyzed using analysis of variance ( $F$ test) and continued with $L S D$ at $5 \%$ level. The results showed that Treatment liquid organic fertilizer (POC)can affect the viability of eggplant (Solanum melongena $L$ ) seeds with parameters observed for seed growth, seed growth speed, vigor index, germination height and seedling wet weight. Concentration of $20 \mathrm{ml}$ of Snail POC/liter of water is the optimal concentration to increase the viability of eggplant (Solanum melongena L.) seeds.
\end{abstract}

Keywords: Snail POC, viability, eggplant seeds

\begin{abstract}
Abstrak
Penelitian pengaruh pupuk organik cair (POC) bekicot terhadap viabilitas benih terung (Solanum melongena L.), dilaksanakan bulan September sampai Oktober Tahun 2018 bertempat di laboratorium Agroteknologi Fakultas Pertanian jalan Provinsi Parit. 1 Tembilahan Hulu. Penelitian bertujuan untuk mengetahui pengaruh pemberian POC Bekicot terhadap viabilitas benih terung (Solanum melongena L.) dan memperoleh kosentrasi POC Bekicot yang optimal. Rancangan penelitian yang digunakan adalah rancangan acak lengkap (RAL) non faktorial, terdiri dari 6 perlakuan, terdiri dari (tanpa perlakuan, $20 \mathrm{ml}$ POC Bekicot/liter air, $30 \mathrm{ml}$ POC Bekicot/liter air, $40 \mathrm{ml}$ POC Bekicot/liter air, $50 \mathrm{ml}$ POC Bekicot/liter air, $60 \mathrm{ml}$ POC Bekicot/liter air dan 3 ulangan. Data yang diperoleh dianalisis secara statistik menggunakan analisis sidik ragam (uji F) dan dilanjutkan dengan LSD pada taraf 5\%. Hasil penelitian menunjukkan bahwa Perlakuan pupuk organik cair (POC) dapat mempengaruhi viabilitas benih terung (Solanum melongena L) dengan parameter pengamatan daya tumbuh benih, kecepatan tumbuh benih, indeks vigor, tinggi kecambah dan berat basah kecambah. Konsentrasi $20 \mathrm{ml}$ POC Bekicot/liter air merupakan kosentrasi optimal untuk meningkatkan viabilitas benih terung (Solanum melongena L.).
\end{abstract}

Kata kunci: Kata Kunci : POC Bekicot, viabilitas, benih terung

\section{PENDAhUluAN}

\subsection{Latar Belakang}

Benih merupakan bahan tanam sangat diperlukan untuk mendapatkan hasil panen yang tinggi. Ketersediaan benih bermutu menjadi hal yang penting untuk kesinambungan produksi tanaman. Penggunaan benih bermutu rendah menyebabkan daya adaptasi tanaman di lapang menjadi berkurang, dan berakibat pada produksi tanaman yang rendah. Mutu benih dapat mengalami kemunduran seiring 
dengan berjalannya waktu dan tidak dapat balik atau irreversibel (Jyoti, 2013).

Perlakuan benih yang harus dilakukan sebelum ditanam adalah memobilisasi sumber daya internal benih untuk memperbesar potensi genetik. Jumlah kandungan metabolit seperti karbohidrat, protein, lemak, asam organik dan hormon akan sangat berpengaruh terhadap fase pertumbuhan karena memberikan bahan makanan dan energi potensial untuk embrio yang sedang tumbuh. Kandungan endosperma merupakan faktor internal biji yang berpengaruh terhadap keberhasilan perkecambahan biji, karena hal ini berhubungan dengan kemampuan biji melakukan imbibisi dan ketersediaan sumber energi kimiawi potensial bagi biji (Supardi, dkk 2016).

Dormansi pada benih dapat disebabkan oleh keadaan fisik dari kulit biji ataupun keadaan fisiologis dari embrio atau kombinasi dari kedua kedaan tersebut. Faktor-faktor yang menyebabkan hilangnya dormansi pada benih sangat bervariasi tergantung pada jenis tanaman dan tipe dormansinya yaitu karena temperatur yang sangat rendah di musim dingin, perubahan temperatur yang silih berganti, menipisnya kulit biji, hilangnya kemampuan untuk menghasilkan zat-zat penghambat perkecambahan dan adanya kegiatan dari mikroorganisme (Lita, 2010).

Dormansi fisik disebabkan oleh impermiabilitas kulit biji terhadap air, resistensi mekanis kulit biji terhadap pertumbuhan embrio, permeabilitas yang rendah dari kulit biji terhadap gas-gas, sedangkan dormansi fisiologis yang disebabkan oleh immaturity embrio, after ripening, dormansi sekunder, dormansi yang disebabkan oleh hambatan metabolis pada embrio. Penyebab dan mekanisme dormansi merupakan hal yang sangat penting diketahui untuk dapat menentukan cara pematahan dormansi yang tepat sehingga benih dapat berkecambah dengan cepat dan seragam. Pada awal fase perkecambahan, biji membutuhkan air untuk mulai berkecambah, hal ini dicukupi dengan menyerap air secara imbibisi dari lingkungan sekitar biji. Setelah biji menyerap air maka kulit biji akan melunak dan terjadilah hidrasi protoplasma, kemudian enzim-enzim mulai aktif, terutama enzim yang berfungsi mengubah lemak menjadi energi melalui proses respirasi (Sutopo, 2002).

Kusumo (1990) berpendapat bahwa salah satu cara perlakuan menggunakan ZPT adalah dengan cara merendam benih. Perendaman ini memungkinkan benih mengalami inbibisi sehingga kadar air benih setelah perendaman akan meningkat dan menstimulir perkecambahan. Untuk membantu mempercepat pertumbuhan dan perkecambahan tanaman dapat digunakan pupuk organik cair (POC) bekicot bagai pengganti pupuk kimia. POC Bekicot mengandung hormon auksin yang dimana salah satu fungsi auksin adalah merangsang pertumbuhan akar dan merangsang proses perkecambahan biji (memecah dormansi biji).

Upaya mematahkan dormansi dapat dilakukan dengan cara mekanik dan perendaman Benih terong kopek varietas Dadali yang direndam pada 100 ppm $\mathrm{GA}_{3}$ selama 24 jam dan dikecambahkan pada arang sekam mempunyai viabilitas dan vigor yang paling tinggi (Fitria, 2001). Prasetya dkk (2017) dalam penelitiannya melaporkan bahwa benih tomat Varietas Royal 58 dengan teknik fermentasi air tomat selama 24 jam efektif dan dapat menunjukkan viabilitas benih yang lebih baik selama masa penyimpanan sampai 12 minggu, sehingga tidak membutuhkan biaya tambahan untuk pembelian larutan maupun bahan lain. Hasil penelitian Farida dan Saragih (2013) menujukkan bahwa pemberian zat pengatur tumbuh atonik 0,50 cc/liter air memberikan perlakuan yang terbaik terhadap rata-rata persentase perkecambahan $75,69 \%$ dan tinggi tanaman jarak pagar. Hasil penelitian Heli, dkk ( 2014) menunjukkan interaksi konsentrasi MOL rebung dan lama perendaman memberikan pengaruh nyata, dan sudah dapat mematahkan dormansi benih kemiri. Hasil terbaik ditunjukkan oleh konsentrasi MOL rebung $40 \mathrm{ml} / \mathrm{I}$ dan lama perendaman 5 jam, dengan kadar air sebesar 11,54\%, daya berkecambah $53,33 \%$, indeks vigor $20 \%$, keserempakan tumbuh 48,33\%, kecepatan tumbuh $1,60 \%$ /etmal, dan laju pertumbuhan kecambah $78,29 \%$

Berdasarkan uraian diatas maka penulis tertarik untuk melakukan penelitian dengan judul " Pengaruh pupuk organik cair bekicot terhadap viabilitas benih terung (Solanum melongena L.)

\section{TINJAUAN PUSTAKA}

\subsection{Botani Tanaman Terung Ungu 2.1.1 Klasifikasi Tanaman Terung Ungu}

Terung merupakan tanaman asl daerah tropis yang dapat tumbuh dengan baik pada ketinggian hingga 1.200 meter di atas permukaan laut diduga berasal dari Asia, terutama India dan Birma, kemudian 
disebarkan ke Cina pada abad ke-5, selanjutnya disebarluaskan ke Karibia, Afrika Tengah, Afrika Timur, Afrika Barat, Amerika Selatan, dan daerah tropis lainnya. Terung disebarkan pula ke negara-negara subtropis, seperti Spanyol dan negara lain di kawasan Eropa. Daerah penyebaran terung yang sangat luas, sehingga sebutan untuk terung sangat beraneka ragam, yaitu eggplant, gardenegg, aubergine, melongene, eierplant, atau eirefruch. Rukmana, (1994). mengemukakan bahwa, tanaman terung dapat diklasifikasikan sebagai berikut:

Diviso : Spermatophyta

Sub divisio : Angiospermae

Kelas : Dycotyledonae

Ordo : Tubiflorae

Famili : Solanaceae

Genus : Solanum

Spesies : Solanum melongena L.

\subsubsection{Morfologi Tanaman Terung}

Terung (Solanum melongena merupakan tanaman setahun berjenis perdu yang dapat tumbuh hingga mencapai tinggi $60-90 \mathrm{~cm}$. Daun tanaman ini lebar dan berbentuk telinga. Bunganya berwarna ungu dan merupakan bunga yang sempurna, biasanya terpisah dan terbentuk dalam tandan bunga (Nazaruddin, 1993).

Tinggi pohon terung $40-150 \mathrm{~cm}$, memiliki daun berukuran panjang $10-20 \mathrm{~cm}$ dan lebar 5-10 cm, bunga berwarna putih hingga ungu memiliki lima mahkota bunga. Berbagai varietas terung tersebar luas di dunia, perbedaannya terletak pada bentuk, ukuran, dan warna tergantung dari varietas terungnya, terung memiliki sedikit perbedaan konsistensi dan rasa. Secara umum terung memiliki rasa pahit dan daging buahnya menyerupai spons. Varietas awa terung memiliki rasa pahit, tetapi terung yang telah mengalami proses penyilangan memiliki perbaikan rasa. Terung merupakan jenis tanaman yang memiliki kedekatan dengan tanaman kentang, tomat, dan paprika (Foodreference, 2010).

Menurut Soetasad dan Muryanti (1999), buah terung merupakan buah sejati tunggal dan berdaging tebal, lunak dan tidak akan pecah meskipun buah telah masak. Daging buahnya tebal, lunak dan berair, daging buah ini merupakan bagian yang enak dimakan. Biji-biji terdapat bebas di dalam selubung lunak yang terlindung oleh daging buah. Pangkal buah menempel pada kelopak bunga yang telah menjelma menjadi karangan bunga.

Morfologi terung ungu memiliki bentuk yang beragam yaitu silindris, lonjong, oval atau bulat. Letak buah terung tergantung dari tangkai buah. Dalam satu tangkai umumnya terdapat satu buah terung, tetapi ada juga yang memiliki lebih dari satu buah. Biji terung terdapat dalam jumlah banyak yang tersebar di dalam daging buah. Daun kelopak melekat pada dasar buah, berwarna hijau atau keunguan.

Bunga terung ungu sering disebut sebagai bunga banci, karena memiliki dua kelamin. Dalam satu bunga terdapat alat kelamin jantan (benang sari) dan alat kelamin betina (putik). Bunga terung bentuknya mirip bintang, berwarna biru atau lembayung, cerah sampai gelap. Penyerbukan bunga dapat berlangsung secara silang maupun menyerbuk sendiri (Rukmana, 1994).

\subsubsection{Syarat Tumbuh Tanaman Terung}

Tanaman terung umumnya memiliki daya adaptasi yang sangat luas, namun kondisi tanah yang subur dan gembur dengan sistem drainase dan tingkat keasamaan yang baik merupakan syarat yang ideal bagi pertumbuhan terung. Untuk pertumbuhan optimum, $\mathrm{pH}$ tanah harus berkisar antara 5,5 - 6,7, namun tanaman terung masih toleran terhadap $\mathrm{pH}$ tanah yang lebih rendah yaitu 5,0. Pada tanah dengan $\mathrm{pH}$ yang lebih rendah dari 5,0 akan menghambat pertumbuhan tanaman yang mengakibatkan rendahnya tingkat produksi tanaman.

Tanaman terung adalah tanaman yang sangat sensitif yang memerlukan kondisi tanam yang hangat dan kering dalam waktu yang lama untuk keberhasilan produksi. Temperatur lingkungan tumbuh sangat mempengaruhi pertumbuhan tanaman dan pencapaian masa berbunga pada terung. Lingkungan tumbuh yang memiliki rata-rata temperatur yang tinggi dapat mempercepat pembungaan dan umur panen menjadi lebih pendek (Samadi, 2001).

Tanaman terung dapat tumbuh baik di dataran rendah hingga dataran tinggi. Terung yang dibudidayakan di dataran rendah dan bertopografi datar mempunyai umur panen yang lebih pendek dibandingkan dengan terung yang dibudidayakan di dataran tinggi.

\subsection{Pupuk Organik Cair (POC)}

Menurut Simanungkalit $d k k$ (2006) pupuk organik cair adalah larutan dari hasil pembusukan bahan-bahan organik yang berasal dari sisa tanaman, kotoran hewan, dan manusia yang kandungan unsur haranya lebih dari satu unsur. Kelebihan dari pupuk organik ini adalah dapat secara cepat 
mengatasi defesiensi hara, tidak bermasalah dalam pencucian hara, dan mampu menyediakan hara secara cepat. Dibandingkan dengan pupuk cair anorganik, pupuk organik cair tidak merusak tanah dan tanaman meskipun digunakan sesering mungkin. Selain itu, pupuk ini juga memiliki bahan pengikat, sehingga larutan pupuk yang diberikan ke permukaan tanaman bisa langsung digunakan oleh tanaman.

Pupuk organik cair dalam pemupukan lebih merata, tidak akan terjadi penumpukan konsentrasi pupuk di suatu tempat, sebab pupuk ini $100 \%$ larut dan merata. Pupuk Organik cair mempunyai kelebihan dapat secara cepat mengatasi difisiensi hara dan tidak bermasalah dalam pencucian hara, juga mampu menyediakan hara secara cepat (Kamal, 2008).

Pupuk organik cair berbahan baku limbah organik memiliki beberapa kelebihan dibandingkan dengan pupuk hayati lain diantaranya sebagai berikut :1). menggunakan sumber daya lokal. Bahan organic yang digunakan berasal dari sumberdaya lokal yang ada disekitar lingkungan tempat budidaya atau perakaran tanaman sehingga mikroorganisme yang dapat berkembang biak bersifat spesifik lokasi. 2). Bahan baku murah dan mudah didapat. Bahan baku pembuatan pupuk organik cair berasal dari limbah kebutuhan sehari-hari seperti limbah tumbuhan. Penggunaan pupuk organik cair dapat menekan biaya yang dikeluarkan oleh petani dan mampu meningkatkan hasil panennya (Pranata, 2010). Penggunaan pupuk organic cair ramah lingkungan,tidak meninggalkan residu pada tanaman dan lingkungan sehingga produk pertanian yang dihasilkan aman bagi kesehatan manusia (Parnata, 2004).

\subsection{Pupuk Organik Cair (POC) Bekicot}

POC bekicot mengandung protein, zotobacter, azospirillium, mikroba pelarut phospat, staphylococcus, pseudomonas, auksin dan enzim. Fungsi auksin menurut adalah 1). Perkecambahan biji. Auksin akan mematahkan dormansi biji (biji tidak mau berkecambah) dan akan merangsang proses perkecambahan biji. Perendaman biji/benih dengan Auksin juga akan membantu menaikkan kuantitas hasil panen. 2). Pembentukkan akar. Auksin akan memacu proses terbentuknya akar serta pertumbuhan akar dengan lebih baik. 3). Pembungaan dan pembuahan. Auksin akan merangsang dan mempertinggi prosentase timbulnya bunga dan buah. 4). Mendorong Partenokarpi. Partenokarpi adalah suatu kondisi dimana tanaman berbuah tanpa fertilisasi atau penyerbukan sehingga dapat menghasilkan buah tanpa biji. 5). Mengurangi gugurnya buah sebelum waktunya. 6). Mematahkan dominansi pucuk / apikal, yaitu suatu kondisi dimana pucuk tanaman atau akar tidak mau berkembang. Manfaat yang diperoleh dari penggunaan POC bekicot sesuai hasil dilapangan diantaranya sebagai adalah dapat mengembalikan dan meningkatkan kesuburan tanah, pada areal sawah yang dipupuk POC Bekicot tampak lebih subur, tanah lebih gembur, terdapat perkembangan cacing dan micro organisme lebih banyak, meningkatkan produksi tanaman, hasil ubinan sebelum menggunakan POC bekicot, menghasilkan 9,1 kg setelah di pupuk mengunakan POC bekicot menjadi 13,5 kg, Kandungan unsur hara yang terdapat pada POC Bekicot lebih mudah diserap tanaman, meningkatkan kualitas pertumbuhan pada tanaman, ramah lingkungan tidak membahayakan termak (Prasetyo, 2012). Hasil analisis Mahdi (2014) POC bekicot mengandung $\mathrm{N}, \mathrm{P}$, dan $\mathrm{K}$ yang tinggi yakni $1,85 \% \mathrm{~N}, 0,89 \% \mathrm{P}, 2,02 \% \mathrm{~K}$ dan $\mathrm{pH} 5,4$

\subsection{Viabilitas Benih}

Viabilitas benih diartikan sebagai kemampuan benih untuk tumbuh menjadi kecambah. Istilah lain untuk viabilitas benih adalah daya kecambah benih, persentase kecambah benih atau daya tumbuh benih. Viabilitas benih merupakan daya kecambah benih yang dapat ditunjukkan melalui gejala metabolisme atau gejala pertumbuhan, selain itu daya kecambah juga merupakan tolok ukur parameter viabilitas potensial benih (Sadjad, 1994). Perkecambahan benih mempunyai hubungan erat dengan viabilitas benih dan jumlah benih yang berkecambah dari sekumpulan benih yang merupakan indeks viabilitas benih.

Viabilitas adalah derajat hidup suatu benih yang aktif secara metabolik, dandapat mensintesis enzim untuk merangsang reaksi perkecambahan dan pertumbuhan benih (Copeland dan Mcdonald 1995). Viabilitas menunjukkan ukuran persentase benih yang hidup setelah penyimpanan (Bicksler 2011). Viabilitas dapat diindikasikan dengan nilai daya berkecambah suatu benih dan vigor benih diindikasikan dengan nilai indeks vigor. Menurut Sadjad (1993), daya berkecambah adalah tolok ukur kemampuan benih untuk tumbuh menjadi tanaman normal yang berproduksi normal dalam keadaan yang optimum. Menurut Widajati et al. (2013), tolok ukur kemampuan benih untuk tumbuh normal dan berproduksi 
normal pada kondisi sub optimum disebut indeks vigor.

Viabilitas benih dipengaruhi oleh banyak faktor, baik dari kondisi benihnya sendiri ataupun faktor dari luar. Menurut Widajati et al. (2013), faktor-faktor yang mempengaruhi viabilitas diantaranya adalah mutu sumber benih, ketersediaan air dalam benih, ketersediaan hara benih, kesehatan benih, suhu yang optimum dancahaya yang cukup. Eskandari (2012) menyatakan bahwa viabilitas benih dipengaruhi oleh fase perkembangan dan kemasakan benih serta kerusakan mekanis benih. Menurut Desai (1997), perlakuan ketika panen dan pasaca panen serta kondisi penyimpanan benih berpengaruh terhadap viabilitas benih.

Konsep periodisasi viabilitas benih Steinbauer-Sadjad menerangkan hubungan antara viabilitas benih dan periode hidup benih. Periode hidup benih dibagi menjadi tiga bagian yaitu periode I, periode II, dan periode III. Periode I adalah periode penumpukan energi (energy deposit) dan juga merupakan periode pembangunan atau pertumbuhan dan perkembangan benih yang diawali dari antesis sampai benih masak fisiologis. Periode II merupakan periode penyimpanan benih atau penambatan energi (energy transit), nilai viabilitas dipertahankan pada periode ini. Akhir periode II adalah kritikal periode dua (KP-2) yang merupakan batas periode simpan benih, setelah KP-2 nilai viabilitas potensial mulai menurun sehingga kemampuan benih untuk tumbuh dan berkembang menurun. Periode II merupakan periode penggunaan energi (energyrelease).

Menurut Copeland dan McDonald (2001), viabilitas benih dapat diukur dengan tolok ukur daya berkecambah (germination capacity). Perkecambahan benih adalah muncul dan berkembangnya struktur terpenting dari embrio benih serta kecambah tersebut menunjukkan kemampuan untuk berkembang menjaditanaman normal pada kondisi lingkungan yang menguntungkan. Viabilitas benih menunjukkan daya hidup benih, aktif secara metabolik dan memiliki enzim yang dapat mengkatalis reaksi metabolik yang diperlukan untuk perkecambahan dan pertumbuhan kecambah.

\section{METODOLOGI PENELITIAN}

\subsection{Tempat dan Waktu Penelitian}

Penelitian dilaksanaka laboratorium Fakultas Pertanian Jalan Provinsi Parit. 1 Tembilahan Hulu Kabupaten Indragiri Hilir
Propinsi Riau pada bulan April sampai Juli Tahun 2021

\subsection{Bahan dan Alat Penelitian}

Bahan yang digunakan dalam penelitian ini adalah benih terung, tanah gambur, pasir, pupuk organic cair (POC) bekicot, air dan pasir, sedangkan alat yang digunakan dalam penelitian ini adalah baki plastik, gelas ukur 100 ml, termometer, penggaris, kamera, kompor, termos, timbangan dan alat tulis.

\subsection{Metode Penelitian}

Rancangan yang digunakan dalam penelitian ini adalah Rancangan Acak Lengkap (RAL) non faktorial yang terdiri dari 6 (enam) perlakuan dengan 3 kali ulangan sehingga terdapat 18 unit perlakuan. Setiap unit percobaan terdiri dari 100 benih terung sehingga totalnya terdapat 1.800 benih terung.

Adapun perlakuannya, yaitu :

$\mathrm{KO}=$ Tanpa perlakuan

$\mathrm{K} 1=20 \mathrm{ml}$ POC Bekicot / liter air

$\mathrm{K} 2=30 \mathrm{ml}$ POC Bekicot / liter air

$\mathrm{K} 3=40 \mathrm{ml}$ POC Bekicot / liter air

$\mathrm{K} 4=\mathrm{ml} 50$ POC Bekicot / liter air

$\mathrm{K} 5=\mathrm{ml} 60$ POC Bekicot / liter air

Data hasil penelitian yang diperoleh dari lapangan dianalisis secara statistik dengan Rancangan Acak Lengkap (RAL) dengan menggunakan rumus sebagai berikut :

Dimana :

$$
Y i j=\mu+K i+E i j
$$

Yij= hasil pengamatan pada perlakuan ke-i dan ulangan ke-j

$\mu=$ Rataan umum

$\mathrm{Ti}=$ pengaruh perlakuan ke-i

$\mathrm{Eij}=$ Pengaruh acak pada perlakuan ke-i ulangan ke-j

Jika pada hasil sidik ragam terdapat perlakuan yang berpengaruh nyata terhadap parameter yang di amati maka dapat di lanjutkan dengan uji lanjut Tukey HSD pada taraf $5 \%$ untuk mengetahui perbedaan masing-masing perlakuan.

\subsection{Pelaksanaan Penelitian 3.4.1 Persiapan Media Semai}

Fase Persiapan merupakan langkah awal yang dilakukan peneliti dalam mempersiapkan berbagai sarana dan prasarana yang dibutuhkan dalam penelitian. Adapun kegiatan-kegiatan yang dilakukan pada fase persiapan meliputi:

a. Mempersiapkan alat dan bahan yang dibutuhkan dalam penelitian. 
Kegiatan diawali dengan mempersiapkan berbagai alat dan bahan yang akan digunakan dalam penelitian, seperti baki plastik, kompor, termos, termometer, penggaris, biji Terung varietas california, air, pasir, amplas dan berbagai alat dan bahan lainnya yang dibutuhkan.

b. Mempersiapkan media semai

Peneliti menyediakan 18 buah baki plastik untuk tempat media semai. Setiap baki diisi dengan pasir cor halus yang sudah dicuci dan dijemur untuk sterilisasi. Pasir diisi setinggi $5 \mathrm{~cm}$ dari tepi atas baki, kemudian media pasir dilembabkan dengan cara menyemprotkan air sampai lembab dengan menggunakan hand sprayer.

\subsubsection{Persiapan Benih Terung}

Benih Terung yang digunakan dalam penelitian ini adalah benih varietas california yang dijual dalam kemasan pabrik. Benih dikeluarkan dari kemasannya sesuai dengan kebutuhan yaitu sebanyak 18000 benih kemudian direndam dengan POC bekicot selama 5 jam sesuai perlakuan.

\subsubsection{Penyemaian Benih}

Sebelum benih Terung disemai, semua benih yang sudah diberi perlakuan dikeringanginkan terlebih dahulu lalu dipindahkan ke media semai. Masing-masing media semai/baki plastik sebanyak 100 biji disusun dengan jarak tanam $2 \mathrm{~cm} \times 2 \mathrm{~cm}$. Setelah itu di atas benih ditaburkan pasir tipis.

\subsection{Pengamatan}

\subsubsection{Daya tumbuh benih (DB)}

Daya tumbuh benih menggambarkan viabilitas potensial benih, dihitung berdasarkan persentase kecambah normal (KN) hitungan pertama (7 hari) dan kedua (14 hari) dari seluruh benih yang ditanam. Pengamatan keragaman kecambah dilakukan terhadap struktur kecambah yang muncul di atas permukaan media semai. Untuk menghitung daya tumbuh benih digunakan rumus :

\section{DB}

\section{EBenith Kecambah Normal $1+$ EBenih Kecambah Normal 2 Jumlah Benih yang diuji}

\subsubsection{Kecepatan Tumbuh Benih (KCT)}

Pengamatan ini mengindikasi Kecepatan Tumbuh karena benih yang lebih cepat tumbuh mampu menghadapi kondisi lapangan yang suboptimal (Surbakti, 1997 dalam Tamin 2004). Pengamatan dilakukan dari umur 1 hari hingga 21 hari setelah semai. Pengamatan dihitung mulai dari stadia pancing

KCT $(\% /$ hari $)=\frac{n 1}{d 2}+\frac{n 2}{d 2} \ldots+\frac{N n}{D n}$

$\mathrm{N} 1-\mathrm{Nn}=$ jumlah kecambah norma pada hari $1,2,3, \ldots$ n

D1 - Dn = Jumlah hari setelah tanam

\subsubsection{Indeks vigor (IV)}

Indeks vigor, menggambarkan vigor kecepatan tumbuh, dihitung berdasarkan persentase kecambah tumbuh normal pada hitungan pertama ( 7 hari setelah tanam).

IV

$=\frac{\text { jumlah Benih Berkeambah Normal Pada Hitungan Pertama }}{\text { jumlah Benithyang difji }}$ x $100 \%$

\subsubsection{Panjang Akar}

Pengukuran dimulai dari bagian bawah kotiledon sampai ujung akar terpanjang dengan menggunakan penggaris. Pengamatan ini dilakukan pada hari ke-14 setelah penyemaian.

\subsubsection{Bobot basah kecambah per baki} (g)

Penghitungan bobot kecambah perbaki dilakukan dengan menimbang seluruh kecambah yang tumbuh di dalam baki masing-masing perlakuan. Pengamatan dilakukan pada hari ke 14 setelah penyemaian

\subsection{Daya Tumbuh Benih (\%)}

Hasil analisis sidik ragam (Lampiran 3a) menunjukkan bahwa pupuk organik cair (POC) bekicot berpengaruh nyata terhadap daya tumbuh benih terung (Solanum melongena L). Hasil uji lanjut dengan LSD pada tahap 5\% disajikan pada Tabel 1 .

Tabel 1. Pengaruh Pupuk Organik Cair (POC) Terhadap Daya Tumbuh Benih Terung (Solanum melongena L.)

\begin{tabular}{lrl}
\hline \multicolumn{1}{c}{ Perlakuan } & $\begin{array}{c}\text { Daya Tumbuh } \\
\text { Benih (\%) }\end{array}$ \\
\hline perlakuan & $51,67 \mathrm{~b}$ \\
POC Bekicot / liter air & $100,00 \mathrm{a}$ \\
POC Bekicot / liter air & $100,00 \mathrm{a}$ \\
POC Bekicot / liter air & $100,00 \mathrm{a}$ \\
POC Bekicot / liter air & $100,00 \mathrm{a}$ \\
BOC Bekicot / liter air & $100,00 \mathrm{a}$ \\
\hline Keterangan :Angka-angka yang diikuti oleh huruf yang \\
berbeda pada kolom yang sama \\
menunjukkan perbedaan yang nyata \\
pada taraf terkecil 5\% menurut uji LSD
\end{tabular}

Tabel 1 menunjukkan bahwa perlakuan pupuk organik cair (POC) bekicot 20-60 ml POC Bekicot/liter air 
mempengaruhi daya tumbuh benih terung (Solanum melongena L) dibandingkan tanpa perlakuan. Hal ini disebabkan karena POC bekicot mengandung auksin, dan unsur hara sehingga dapat menstimulasi perkecambahan dan pertumbuhan biji tanaman auksin dalam tubuh tanaman akan mengaktifkan pembentukan sel-sel baru dalam tubuh tanaman. Menurut Azwar (2008) dalam Prayitna (2017) auksin berfungsi sebagai pengatur pembesaran sel dan memicu pemanjangan sel di daerah belakang meristem ujung. Auksin membantu proses pertumbuhan vegetatif dan merangsang pertumbuhan akar. Menurut Agrawal (1980), proses perkecambahan tersebut penting untuk mengindikasikan kemampuan benih berkembang menjadi tanaman normal di bawah kondisi yang sesuai di dalam tanah, sehingga daya berkecambah tersebut merupakan indikator bagus atau tidaknya benih yang akan ditanam di lahan.

Kandungan unsur hara yang terdapat pada POC bekicot, seperti N sebesar 1,85\% juga mempengaruhi daya tumbuh benih terung (Solanum melongena L). Menurut Lakitan (2000) unsur $\mathrm{N}$ berfungsi sebagai penyusun senyawa esensial untuk pertumbuhan dan pembelahaan sel. Selanjutnya Viktorius $d k k$ (2017) auksin akan mempercepat permeabilitas masuknya air kedalam sel, mempertinggi penyerapan diantaranya unsur N, Mg, Fe, Cu serta dapat menaikkan tekanan osmotik menyebabkan pengurangan tekanan pada dinding sel, meningkatkan sintesis protein, meningkatkan plastisitas dan pengembangan dinding sel.

\subsection{Kecapatan Tumbuh Benih (\%hari)}

Hasil analisis sidik ragam (Lampiran 3b) menunjukkan pupuk organik cair (POC) bekicot berpengaruh nyata terhadap kecepatan tumbuh benih terung (Solanum melongena L). Hasil uji lanjut dengan LSD pada tahap 5\% disajikan pada Tabel 2.

Tabel 2. Pengaruh Pupuk Organik Cair (POC) Terhadap Kecepatan Tumbuh Benih Terung (Solanum melongena $\mathrm{L}$ )

\begin{tabular}{lc}
\hline Perlakuan & $\begin{array}{c}\text { Kecepatan } \\
\text { Tumbuh Benih } \\
(\% / \text { hari })\end{array}$ \\
\hline perlakuan & $11,11 \mathrm{~d}$ \\
POC Bekicot / liter air & $21,58 \mathrm{a}$ \\
POC Bekicot / liter air & $20,51 \quad$ ab \\
POC Bekicot / liter air & $19,36 \quad$ bc \\
POC Bekicot / liter air & $18,42 \quad \mathrm{c}$ \\
POC Bekicot / liter air & $18,13 \quad \mathrm{c}$ \\
\hline
\end{tabular}

Keterangan :Angka-angka yang diikuti oleh huruf yang berbeda pada kolom yang sama menunjukkan perbedaan yang nyata pada taraf terkecil 5\% menurut uji LSD.

Tabel 2 menunjukkan bahwa perlakuan pupuk organik cair (POC) bekicot mempengaruhi kecepatan tumbuh benih terung (Solanum melongena L) dibandingkan tanpa perlakuan. Kecepatan tumbuh benih tercepat diperoleh pada benih terung (Solanum melongena $\mathrm{L}$ ) dengan perlakuan $20 \mathrm{ml}$ POC Bekicot/liter air, tetapi kecepatan tumbuh menurun dengan meningkatnya kosentrasi POC bekicot. Hal ini karna $20 \mathrm{ml}$ POC Bekicot/liter merupakan kosentrasi yang optimal dalam mendorong perkecambahan benih. Menurut Gardner dkk, (2008) ZPT merupakan senyawa organik yang akan memberikan efek fisiologis pada konsentrasi rendah. Salisbury dan Ross (1995) menyatakan bahwa pemberian auksin dapat memacu pemanjangan potongan akar atau bahkan akar utuh pada pada konsentrasi yang sangat rendah (10 -7 sampai $10-13 \quad M$, bergantung pada jenis dan umur akar). Pada konsentrasi yang lebih tinggi (tapi masih cukup rendah, antara 1 sampai $10 \mu \mathrm{M}$ ), pemanjangan hampir selalu terhambat.

Pangaribuan (2012) hormon adalah senyawa organik bukan nutrisi yang aktif dalam jumlah yang kecil yang dibutuhkan pada bagian tertentu pada umumnnya ditranslokasikan ke bagian lain tanaman, dimana senyawa tersebut menghasilkan suatu tanggapan secara biokimia, fisiologi dan morfologis. Menurut (Wattimena et al., 1992 ) peran fisiologis auksin adalah mendorong perpanjangan sel, pembelahan sel, differensiasi jaringan xilem dan floem, pembentukan akar

\subsection{Indeks Vigor}

Hasil analisis sidik ragam (Lampiran 3a) menunjukkan bahwa pupuk organik cair (POC) bekicot berpengaruh nyata terhadap indeks vigor benih terung (Solanum melongena L). Hasil uji lanjut dengan Tukey HSD pada tahap 5\% disajikan pada Tabel 3. Tabel 3. Pengaruh Pupuk Organik Cair (POC) Terhadap Indeks Vigor Benih Terung (Solanum melongena L.)

\begin{tabular}{lrl}
\hline \multicolumn{1}{c}{ Perlakuan } & \multicolumn{2}{c}{ Indeks vigor } \\
\hline perlakuan & 51,67 & $\mathrm{C}$ \\
POC Bekicot / liter air & 100,00 & $\mathrm{a}$ \\
POC Bekicot / liter air & 100,00 & $\mathrm{a}$ \\
POC Bekicot / liter air & 100,00 & $\mathrm{a}$ \\
POC Bekicot / liter air & 93,33 & $\mathrm{~b}$ \\
POC Bekicot / liter air & 100,00 & a \\
\hline Keterangan :Angka-angka yang diikuti oleh huruf yang
\end{tabular}


menunjukkan perbedaan yang nyata pada taraf terkecil 5\% menurut uji LSD.

Tabel 3. menunjukkan bahwa perlakuan pupuk organik cair (POC) bekicot mempengaruhi indeks vigor benih terung (Solanum melongena $\mathrm{L}$ ) dibandingkan tanpa perlakuan. Perlakuan 20, 30, 40, 50 dan 60 $\mathrm{ml}$ POC bekicot/liter air mampu menghasilkan indeks vigor yang lebih tinggi dibandingkan tanpa perlakuan. Hal ini menunjukkan bahwa auksin yang terkandung pada POC bekicot dapat memacu perkecambahan biji 7 hari setelah semai benih sudah mempunyai daya tumbuh yang tinggi. Hal ini disebabkan karena adanya penambahan air yang mampu melunakkan kulit benih terung dan adanya sumbangan hormon tumbuh auksin dari POC bekicot. Menurut Davies (2004) menyatakan bahwa hormon auksin mampu mempercepat perkecmbahan. Cara kerja auksin dalam perkecambahan biji diawali dengan terjadinya imbibisi air merangsang sintesis hormon, lalu hormon tersebut berdifusi ke lapisan aleuron dan merangsang sintesis enzim.

Harjadi (2002) menyatakan bahwa air merupakan syarat essensial untuk perkecambahan dengan kebutuhan yang bervariasi tergantung spesies yang ada. Seledri membutuhkan kandungan air mendekati kapasitas lapang sedangkan tomat akan berkecambah dengan kandungan air media di atas titik layu permanen. Untuk kebanyakan benih, kondisi lewat basah sangat merugikan karena menghambat aerasi dan merangsang kondisi yang diinginkan oleh perkembangan penyakit.

\subsection{Tinggi Kecambah ( $\mathrm{cm})$}

Hasil analisis sidik ragam (Lampiran 3d) menunjukkan bahwa pupuk organik cair (POC) bekicot berpengaruh nyata terhadap tinggi kecambah terung (Solanum melongena L). Hasil uji lanjut LSD pada tahap 5\% disajikan pada Tabel 4.

Tabel 4. Pengaruh Pupuk Organik Cair (POC) Terhadap Tinggi kecambah Terung (Solanum melongena L.)

\begin{tabular}{lll}
\hline \multicolumn{1}{c}{ Perlakuan } & \multicolumn{1}{c}{ Tinggi kecamba } \\
\hline perlakuan & $5,53 \mathrm{C}$ \\
POC Bekicot / liter air & $7,50 \mathrm{a}$ \\
POC Bekicot / liter air & $6,63 \mathrm{~b}$ \\
POC Bekicot / liter air & $6,33 \mathrm{~b}$ \\
POC Bekicot / liter air & $6,85 \mathrm{~b}$ \\
POC Bekicot / liter air & 7,21 a \\
\hline Keterangan :Angka-angka yang diikuti oleh huruf yang \\
berbeda pada kolom yang sama \\
menunjukkan perbedaan yang nyata \\
pada taraf terkecil 5\% menurut uji LSD.
\end{tabular}

Tabel 4 menunjukkan bahwa perlakuan 20 dan $60 \mathrm{ml}$ pupuk organik cair (POC) bekicot memberikan tinggi kecambah paling tinggi dibandingkan perlakuan 30,40 dan $50 \mathrm{ml}$ pupuk organik cair (POC) bekicot dan tanpa perlakuan. Hal ini disebabkan karena pada perlakuan ini kebutuhan air benih terpenuhi dan adanya penambahan hormon pertumbuhan yang dapat merangsang pertumbuhan benih sehingga benih lebih cepat tumbuh (Tabel 3) dan lebih tinggi. Hal ini disebabkan karena pertumbuhan tinggi kecambah berhubungan dengan daya tumbuh benih, kecepatan tumbuh benih dan indeks vigor benih yang tinggi. Menurut Sastrahidayat (2011) penyerapan air dan unsur hara yang cukup oleh tanaman menyebabkan pertumbuhan tanaman menjadi lebih baik, yang ditunjukkan dengan pertumbuhan tinggi tanaman yang optimal. Menurut Sutopo (2004) panjang kecambah suatu tanaman di tentukan oleh ukuran benih pada berbagai kecambah, dan juga dipengaruhi oleh viabilitas benih

Tinggi kecambah atau Panjang hipokotil merupakan ukuran tanaman yang sering diamati baik sebagai indikator pertumbuhan maupun sebagai parameter yang digunakan untuk mengukur pengaruh lingkungan atau perlakuan yang diterapkan. Ini didasarkan atas kenyataan bahwa panjang hipokotil tanaman merupakan ukuran pertumbuhan yang paling mudah dilihat. (Sitompul dan Guritno) dalam (Indria, 2005).

\subsection{Bobot Basah Kecambah per Baki} (g)

Hasil analisis sidik ragam (Lampiran 1) menunjukkan bahwa pupuk organik cair (POC) bekicot berpengaruh nyata terhadap bobot basah kecambah terung (Solanum melongena L). Hasil uji lanjut dengan Tukey HSD pada tahap 5\% disajikan pada Tabel 5. Tabel 5. Pengaruh Pupuk Organik Cair (POC) Terhadap Bobot Basah Kecambah Terung (Solanum melongena $\mathrm{L}$ )

\begin{tabular}{lrr}
\hline (cm) Perlakuan & \multicolumn{2}{c}{$\begin{array}{c}\text { Bobot basah } \\
\text { kecambah }(\mathbf{g})\end{array}$} \\
\hline perlakuan & 2,25 & $\mathrm{~d}$ \\
POC Bekicot / liter air & 5,22 & $\mathrm{a}$ \\
POC Bekicot / liter air & 4,81 & $\mathrm{~b}$ \\
POC Bekicot / liter air & 3,68 & $\mathrm{C}$ \\
POC Bekicot / liter air & 4,83 & $\mathrm{~b}$ \\
POC Bekicot / liter air & 4,04 & $\mathrm{~b}$ \\
\hline Keterangan :Angka-angka yang diikuti oleh huruf \\
\multicolumn{4}{c}{ yang berbeda pada kolom yang } \\
\multicolumn{4}{c}{ sama menunjukkan perbedaan yang }
\end{tabular}


nyata pada taraf terkecil 5\% menurut uji LSD.

Tabel 5 menunjukkan bahwa bobot basah kecambah benih terung (Solanum melongena $\mathrm{L}$ ) dengan perlakuan $20 \mathrm{ml}$ POC Bekicot/liter air memiliki bobot basah kecambah tertinggi dibandingkan perlakuan lainnya, walaupun secara statistik berbeda tidak nyata dengan perlakuan $60 \mathrm{ml}$ POC Bekicot / liter air. Bobot basah yang tinggi pada perlakuan dipengaruhi oleh kecepatan tumbuh benih (Tabel 1 ) dan tinggi benih (Tabel 4) dan jumlah dosis POC yang diberikan. Perlakuan $20 \mathrm{ml}$ POC Bekicot/liter air merupakan kosentrasi yang optimal untuk perkecambahan terung dimana peningkatan dosis POC malah menurunkan bobot basah kecambah. Dwidjoseputro (1994) menyatakan bahwa biji bijian memiliki kadar air yang rendah. Temperatur optimum belum juga dapat menyebabkan tumbuhnya biji jika biji masih dalam keadaan kering, Setelah ada imbibisi air, maka mulailah biji itu tumbuh. Hal ini berkaitan dengan adanya pengaruh air terhadap aktivitas enzim, sewaktu biji kering maka aktivitas enzim sama sekali tidak tampak.

\section{KESIMPULAN DAN SARAN}

\subsection{Kesimpulan}

1. Perlakuan pupuk organik cair (POC) dapat mempengaruhi viabilitas benih terung (Solanum melongena L) dengan parameter pengamatan daya tumbuh benih, kecepatan tumbuh benih, indeks vigor, tinggi kecambah dan berat basah kecambah

2. Konsentrasi POC bekicot yang optimal untuk meningkatkan viabilitas benih terung (Solanum melongena L.) adalah $20 \mathrm{ml}$ POC Bekicot/liter air

\subsection{Saran}

Setelah melakukan penelitian, penulis menyarankan untuk melakukan penelitian yang serupa tetapi menggunakan benih yang sudah disimpan lama.

\section{DAFTAR PUSTAKA}

1. Andreoli C, Khan AA. 1993. Improving papaya seedling emergence by matriconditioning and gibberellin treatment. Cornell University, Geneva. Hort Science 28(7):708-709.

2. Arnold RLB, RA Sanchez, F Forcella, BC Kruk and CM Ghersa. 2000. Environmental control of dormancy in weed seed banks in soil. FieldCrops Research (67):105-122

3. Baskin, CC, Baskin, JM. 1998 Seeds: Ecology, Biogeography andEvolution of Dormancy and Germination. Academic Press, San Diego.

4. Bautista Calles F, Castaneda GC, Monter AG. 2008. Recuperation of the High Germinability Condition of Papaya Seed Through Priming Technology and Bioregulators. J.Agrociencia (42): 7; 817-826.

5. Bewley JD, Black M. 1985. Physiology and Biochemistry of Seeds Berlin Heidelberg New York: Springer-Verlag.

6. Chan YK. 1994. Development of F1 Hybrids for papaya (Carica papaya L) Seed Production and performance of F1 hybrids. Disertasi , Universiti of Malaya Malaysia 34p

7. Copeland LO, McDonald MB. 2001. Principles of Seed Science and Technology (Fourth Edition). New York. Chapmand and Hall. 409p.

8. Dias DCFS, Wagner DTE, Fernando LF, Eveline MA, Luiz ADS. 2010. Physiological and enzymatic alterations in papaya seed during strorage. Revista Brasileira de Sementes,(32):1:148-157.

9. Eira MTS, LS Caldas. 2000. Seed ormancy and germination as concurrent processes. R. Bras. Fisiol. Veg ; 12 (Edição Especial):85-104.

10. Ellis, R. H., Hong, T. D., Robert, E. H., 1983. Procedure for the safe removal of dormancy in rice seed. Seed Sci \&Technol 11:77-112.

11. Erista. 2000. Pengaruh pengeringan dan tingkat kadar air terhadap viabilitas dan tingkat kadar air kritis benih kakao (Theobroma cacao L) [Thesis] Bogor: Sekolah Pascasarjana, Institut Pertanian Bogor .

12. Faustina, E., Prapto, Y. \& Rabaniyah, R. (2012). Pengaruh Cara Pelepasan Aril dan Konsentrasi KNO3 Terhadap Pematahan Dormansi Benih Pepaya (Carica papaya L.) 1, 42-52. (Online) http://jurnal.ugm.ac.id/jbp/article/downl oad/1383/pdf_17. Diakses 1 Januari 2015

13. Furutani, S. C., M. A. Nagao. 1987. Influence of temperature, KNO3, GA3 and seed drying on emergence of papaya seedling. Scientia Horticulturae 32:67-72.

14. Kalie MB, 2001. Bertanam Pepaya. Jakrta : Penebar Swadaya

15. Kuswanto H. 2003. Teknologi Pemrosesan, Pengemasan, dan 
Penyimpanan Benih. Yogyakarta. Kanisius. 127 hal.

16. Lita, S. (2010). Teknologi Benih. Jakarta : RAJAWALI PERS

17. Melvin S. Nishina, Mike A. Nagao1, and Sheldon C. Furutani. 2004. Optimizing Germination of Papaya Seeds. Fruit and Nuts. Cooperative extension service. College of Tropical Agriculture and Human Resources (CTAHR).

18. Nakasone, H. Y and R. E. Paull. 1998. Papaya, p. 239-269. In: Jeff Atherton and Alun Rees (Eds). Tropical Fruits. CBA Internasional Publising. London.

19. Oben. Bintoro, A. Riniarti, M. 2014. Pengaruh Perendaman Benih Pada Berbagai Suhu Awal Air Terhadap Viabilitas Benih Kayu Afrika (Maesopsis eminii). Jurnal Sylva Lestari. 2(1).

20. Pachey N,Vearasilp S, Krittigamas N, Sangtiwa S. 2003. Various Drying Technique Affected Papaya Seeds Qualities [abstrak]. Di dalam : Simposium Technological and Institutional Innovations forSustainable Rural Development; Gottingen, 8-10 Okto 2003, Chiang Mai University, Department of Agronomy. Thailand.

21. Pammenter NW, Greggains V, Kioko JI, Smith JW, Berjak P, Finch Savege WE. 1998. Effect of differential drying rates on viabilit retention of recalcitrant seed of Ekebergia capensis. Seed Sci Res. 8:463-471.

22. Purnomo. 1999. Petunjuk Praktikum Pengolahan Pangan. Diktat jurusan Teknologi Pangan dan Gizi. Fakultas Teknologi Pertanian Institut Pertanian Bogor, Bogor.

23. Purnomo. 1999. Petunjuk Praktikum Pengolahan Pangan. Diktat jurusan Teknologi Pangan dan Gizi. Fakultas Teknologi Pertanian Institut Pertanian Bogor, Bogor.

24. Pusat Kajian Hortikultura Buah-Buahan Tropika. 2008. Profil Produk Pengembangan Buah Unggulan. LPPM Institut Pertanian Bogor. Bogor. 14 hal.

25. Rahardi, F. 2004. Mengurai Benang Kusut Agribisnis Buah Indonesia. Penebar Swadaya. Jakarta. 152 hal.

26. Ross, P. S. (2000) Marine mammals as sentinels in ecological risk assessment. Human and Ecological Risk Assessment (in press)

27. Sadjad, S. 1994. Teknologi benih dengan masalah-masalahnya. Di dalam: Sadjad S, editor. Dasar-dasar teknologi Benih. Capita Selecta. Bogor: Departemen Agronomi Fakultas Pertanian IPB
28. Salomoa AN, Mundim RC. 2000. Germination of papaya seed in response to desiccation, exposure to subzero temperatures and gibberellic acid. Hort. Science. 35 (5): 904-906.

29. Sari, H. P. 2005. Pertumbuhan dan Daya Kecambah (Mucuna bracteata D.C.) Melalui Pematahan Dormansi dan Pemberian Zat Pengatur Giberelin (GA3). Skripsi. Program Studi Agroekoteknologi. Fakultas Pertanian. Universitas Sumatera Utara. Medan.

30. Sobir. 2009. Sukses Bertanam Pepaya Unggul Kualitas Supermarket. Agromedia Pustaka, Jakarta

31. Suketi, K., R. Poerwanto, S. Sujiprihati, Sobir dan W. D. Widodo. 2011a. Karakter fisik dan kimia buah pepaya pada stadia kematangan berbeda. J. Agron. Indonesia 38(1):60-66.

32. Sunyoto, 2010, "Adobe Flash $+X M L=$ Rich Multimedia Application", Andi Offset, Yogyakarta.

33. Suwarno, F. C. 1984. Pengaruh cahaya dan perlakuan benih terhadap perkecambahan benih pepaya (caricca papaya L) Bulletin Agronomi, 15 (3):48 $-60$

34. Vazquez_YC, Orozco SA , MEC. Snchez, M. Rojas_Arechigo and A. I. Batis. 1999. Seed ecology at the northern limit of the tropical rain forest in America, p375-388 In:M. Black, K. J Bradfort. And J.Vazquez_Ramos. Seed Biology Advances and Applications. CABI.

35. Villegas. 1997. Carica papaya L. In Verheij, EWM \& Coronel, RE (eds.) Plant resources of Sount East Asia 2 : Edible fruits and nuts, Prosea Foundation, pp. 125-31.

36. Walters C, and L Towill. 2000. Seed and Pollen National Center for Genetic Resources Preservation. Preservation of Plant Germplasm Research USDA-ARS. Fort Collins. Co. 8p.

37. Wood CB, Pritchard HW, Amritphale D. 2000. Desiccation-induced dormancy in papaya (Carica papaya L.) seeds is alleviated by Heatshock. Seed Science Research(2000),10: 135-145 [http://www.mmnpjournal. org.Abstrac [20 Okto 2011].

38. Wulandari, R. 2009. Pengujian Benih Pepaya (Carica papaya L.) dengan Penyimpanan Suhu Dingin . Skripsi. Departemen Budidaya Pertanian, Institut Pertanian Bogor. Bogor. 37 hal. 
